\title{
Neuroprotective strategies and the underlying molecular basis of cerebrovascular stroke
}

\author{
Michael Karsy, MD, PhD, Andrea Brock, MD, MSci, Jian Guan, MD, Phillip Taussky, MD, \\ M. Yashar S. Kalani, MD, PhD, and Min S. Park, MD \\ Department of Neurosurgery, Clinical Neurosciences Center, University of Utah, Salt Lake City, Utah
}

\begin{abstract}
Stroke is a leading cause of disability in the US. Although there has been significant progress in the area of medical and surgical thrombolytic technologies, neuroprotective agents to prevent secondary cerebral injury and to minimize disability remain limited. Only limited success has been reported in preclinical and clinical trials evaluating a variety of compounds. In this review, the authors discuss the most up-to-date information regarding the underlying molecular biology of stroke as well as strategies that aim to mitigate this complex signaling cascade. Results of historical research trials involving $N$-methyl-D-aspartate and $\alpha$-amino-3-hydroxy-5-methyl-4-isoxazole propionate receptor antagonists, clomethiazole, antioxidants, citicoline, nitric oxide, and immune regulators have laid the groundwork for current progress. In addition, more recent studies involving therapeutic hypothermia, magnesium, albumin, glyburide, uric acid, and a variety of other treatments have provided more options. The use of neuroprotective agents in combination or with existing thrombolytic treatments may be one of many exciting areas of further development. Although past trials of neuroprotective agents in ischemic stroke have been limited, significant insights into mechanisms of stroke, animal models, and trial design have incrementally improved approaches for future therapies.
\end{abstract}

https://thejns.org/doi/abs/10.3171/2017.1.FOCUS16522

KEY WORDS neuroprotection; stroke; cerebrovascular accident; intraparenchymal hemorrhage; intracerebral hemorrhage

$\mathrm{C}$ EREBROVASCULAR ischemia, or stroke, affects up to 800,000 US individuals yearly and is a leading cause of disability, costing $\$ 34$ billion per year in health care expenses, disability, and lost productivity. ${ }^{109}$ Although there have been significant advances in intravenous tissue plasminogen activator (TPA) and mechanical thrombectomy approaches, there remains a significant need for additional neuroprotective and neuroregenerative therapies ${ }^{74,109,136}$ Neuroprotection involves strategies to interrupt the cascade of cell injury leading to infarction. ${ }^{51}$ Approximately $85 \%$ of stroke is ischemic and $15 \%$ of stroke is hemorrhagic; however, the use of neuroprotective agents may be beneficial and specific to both types. ${ }^{109}$

The number of studies involving neuroprotective treatments has increased exponentially since elucidation of the molecular mechanisms of stroke in the 1970s. Preclinical and clinical studies have further improved the pathophysi- ological understanding of ischemic stroke and helped focus development of further approaches. ${ }^{48}$ However, great challenges remain in identifying agents with significant therapeutic efficacy. Currently, there is no US Food and Drug Administration-approved agent for neuroprotection after ischemic stroke. Despite this hurdle, ongoing studies are investigating various approaches. The Internet Stroke Center (http://www.strokecenter.org/) describes 3867 active or completed trials, including 60 trials regarding neuroprotective agents, with many that are actively recruiting patients (Table 1). Similarly, clinicaltrials.gov reports 58 studies evaluating neuroprotection that are actively recruiting, including for ischemic stroke and other neurological pathologies. Various state and national stroke registries have also been key in organizing collaborations between various hospitals and serving as a source of information for neuroprotection clinical trials. The purpose

ABBREVIATIONS AMPA = $\alpha$-amino-3-hydroxy-5-methyl-4-isoxazole propionate; ATP = adenosine 5'-triphosphate; GABA = $\gamma$-aminobutyric acid; IL = interleukin; mRS = modified Rankin Scale; NIHSS = National Institutes of Health Stroke Scale; NMDA = N-methyl-D-aspartate; RCT = randomized controlled trial; SUR1-TRPM4 = sulfonylurea receptor 1-transient receptor potential melastatin 4; TPA = tissue plasminogen activator.

SUBMITTED December 1, 2016. ACCEPTED January 12, 2017.

INCLUDE WHEN CITING DOI: 10.3171/2017.1.FOCUS16522. 
TABLE 1. Current trials actively enrolling patients for neuroprotective treatment strategies

\begin{tabular}{|c|c|c|}
\hline Trial Name & Trial Abbreviation & Trial No. \\
\hline $\begin{array}{l}\text { Study to Assess the Safety, Pharmacokinetics, and Pharmacodynamics of DS-1040b in Subjects With } \\
\text { Acute Ischemic Stroke }\end{array}$ & ASSENT & NCT02586233 \\
\hline Administration of Statin On Acute Ischemic Stroke Patient Trial & ASSORT & NCT02549846 \\
\hline Cooling Plus Best Medical Treatment Versus Best Medical Treatment Alone for Acute Ischaemic Stroke & EuroHYP-1 & NCT01833312 \\
\hline $\begin{array}{l}\text { Effects of Cerebral Protection With Filters vs. Flow Reversal on Cerebral Embolization After Carotid } \\
\text { Artery Stenting }\end{array}$ & & NCT01414387 \\
\hline Effects of Surface Cooling On Stroke Outcome Trial & $\mathrm{COOL}$ & NCT02176993 \\
\hline $\begin{array}{l}\text { Efficacy and Safety Study of GM602 in Patients With Acute Middle Cerebral Artery Ischemic Stroke } \\
\text { Within } 18 \text { Hours }\end{array}$ & GMAIS & NCT01221246 \\
\hline Field Randomization of NA-1 Therapy in Early Responders & FRONTIER & NCT02315443 \\
\hline Hydroxyurea to Prevent Brain Injury in Sickle Cell Disease & HUPrevent & NCT01389024 \\
\hline Implant for Augmentation of Cerebral Blood Flow Trial, Effectiveness and Safety in a 24-Hour Window & ImpACT-24 & NCT00826059 \\
\hline $\begin{array}{l}\text { Intensive Insulin Therapy With Tight Glycemic Control to Improve Outcomes After Endovascular Therapy } \\
\text { for Acute Ischemic Stroke }\end{array}$ & & NCT02054429 \\
\hline Intra-arterial Bone-Marrow Mononuclear Cells Infusion for Acute Ischemic Stroke & & NCT02178657 \\
\hline Neuroprotection of Pioglitazone in Acute Ischemic Stroke & & NCT02195791 \\
\hline $\begin{array}{l}\text { Neuroprotection with Statin Therapy for Acute Recovery Trial (Neu-START): A Phase II safety and pilot } \\
\text { efficacy study of lovastatin for the treatment of acute ischemic stroke [SPOTRIAS] }\end{array}$ & $\begin{array}{l}\text { Neu-START II/ } \\
\text { SPOTRIAS }\end{array}$ & NCT00243880 \\
\hline $\begin{array}{l}\text { Neuroprotective Effect of Autologous Cord Blood Combined With Therapeutic Hypothermia Following } \\
\text { Neonatal Encephalopathy }\end{array}$ & & NCT02551003 \\
\hline $\begin{array}{l}\text { Neuroprotective Goal Directed Hemodynamic Optimization in Post-Cardiac Arrest Patients: a Random- } \\
\text { ized Controlled Trial (the NEUROPROTECT Post-CA Trial) }\end{array}$ & NEUROPROTECT & NCT02541591 \\
\hline Remote Ischaemic Conditioning After Stroke Trial & ReCAST-2 & NCT02779712 \\
\hline Remote Ischemic Conditioning in Acute Brain Infarction Study & RESCUE-BRAIN & NCT02189928 \\
\hline Safety Evaluation of 3K3A-APC in Ischemic Stroke & RHAPSODY & NCT02222714 \\
\hline Stroke and Tocotrienol: Unique Role in Neuroprotection & SATURN & NCT02263924 \\
\hline Study of Compound Edaravone Injection for Treatment of Acute Ischemic Stroke & & NCT02430350 \\
\hline Subcutaneous Interleukin-1 Receptor Antagonist (SC IL-1RA) in Stroke Study & & ISRCTN74236229 \\
\hline The Effect of GLP-1 Receptor Agonist on Cerebral Blood Flow Velocity in Non-Stroke Volunteers & EGRABINS1 & NCT02838589 \\
\hline The Effect of GLP-1 Receptor Agonist on Cerebral Blood Flow Velocity in Stroke & EGRABIS1 & NCT02829502 \\
\hline The Efficacy of Citalopram Treatment in Acute Stroke & TALOS & NCT01937182 \\
\hline The RIGHT Trial: Rapid Intervention with Glyceryl Trinitrate (GTN) in Hypertensive Stroke Trial & RIGHT & ISRCTN26986053 \\
\hline Safety Evaluation of 3K3A-APC in Ischemic Stroke & RHAPSODY & NCT02222714 \\
\hline $\begin{array}{l}\text { The Safety and Efficacy Study of High-Dose Atorvastatin After Thrombolytic Treatment in Acute Ischemic } \\
\text { Stroke }\end{array}$ & SEATIS & NCT02452502 \\
\hline Stroke Hyperglycemia Insulin Network Effort (SHINE) Trial & SHINE & NCT01369069 \\
\hline
\end{tabular}

of this review is to discuss recent studies regarding the molecular mechanism of stroke, clinical trial findings, and potential future approaches.

\section{Pathophysiology of Ischemic Stroke}

A complex, coordinated, and interrelated cascade of molecular events follows brain ischemia and infarction. Ischemia is defined as a reduction in blood flow sufficient to cause an alteration of normal cellular function; hypoxia is defined as a reduction of tissue oxygen to levels insufficient to maintain homeostasis. Initial events after ischemia result in necrosis of core infarcted tissue with reduced blood flow, maintained metabolism, and reduced function of adjacent penumbra tissue. ${ }^{16}$ After disruption of adenosine 5'-triphosphate (ATP) generation and the $\mathrm{Na}^{+}$/
$\mathrm{K}^{+}$transporter, cellular depolarization allows $\mathrm{Ca}^{2+}$ influx, resulting in activation of the intrinsic apoptosis pathway and cell death. ${ }^{86}$ Glutamate accumulation in the extracellular space results in activation of $N$-methyl-D-aspartate (NMDA), $\alpha$-amino-3-hydroxy-5-methyl-4-isoxazole propionate (AMPA), and kainate glutamate receptors, which mediate $\mathrm{Ca}^{2+}$ influx. ${ }^{87}$

Increased oxidative stress occurs during free radical formation by superoxide, hydroxyl radical, nitric oxide, and peroxynitrite, with reduction of energy-dependent scavenger enzymes during stroke. ${ }^{94}$ Free radical generation also occurs from arachidonic acid metabolism, ${ }^{59}$ infiltrating peripheral leukocytes, ${ }^{138}$ and upregulation of inducible nitric oxide synthase by microglia and monocytes, ${ }^{156}$ all of which are seen during acute stroke. Free radicals and $\mathrm{Ca}^{2+}$ 
induce inflammatory cytokines (e.g., interleukin [IL]-1, IL-6, tumor necrosis factor- $\alpha$ ) and chemokines (e.g., IL8, MCP-1) as well as endothelial cell adhesion molecules (e.g., selectins, ICAM-1, VCAM-1) and proinflammatory genes. ${ }^{32,70,156}$ Free radicals also result in lipid peroxidation, induction of apoptosis, and production of 4-hydroxynonenal, which covalently modifies the $\mathrm{Na}^{+} / \mathrm{K}^{+}$ATPase, glucose, and glutamate transporters to impair function. ${ }^{101}$

Distinct cell populations also play important roles in ischemic response. Critical to the process of inflammation is the role of microglia within the ischemic penumbra, which produce proinflammatory cytokines, toxic metabolites, and enzymes..$^{29,115}$ Astrocytes also produce proinflammatory cytokines and neuroprotective factors (e.g., erythropoietin, transforming growth factor- $\beta$, metallothionein-2). ${ }^{104}$ Endothelial changes can also result in bloodbrain barrier dysfunction and increased inflammatory response. ${ }^{28}$ Infiltration of circulating leukocytes, including polymorphonuclear leukocytes and $\mathrm{T}$ cells, impairs recovery after ischemic stroke. ${ }^{2,46,67,100}$ Increased cerebral edema after ischemic stroke also plays a role in poorer patient prognosis. ${ }^{137}$ Involvement of the sodium-hydrogen antiporter family members, sulfonylurea receptor 1-transient receptor potential melastatin 4 (SUR1-TRPM4) cation channel, and aquaporin-4 is particularly important in mediating increased cerebral edema after ischemic stroke. Hemorrhagic stroke also differs from ischemic stroke with the release of cytotoxic hemoglobin, upregulation of the acute phase proteins haptoglobin and hemopexin, and increased oxidative stress (Fig. 1). ${ }^{10}$

\section{Key Historical Clinical Findings}

Although many preclinical studies have helped to improve understanding of ischemic stroke (Table 2), the studies often differed substantially in terms of animal factors, treatment conditions, models of ischemia, timing of treatment, and outcome assessment. From 1995 to 2015, 430 potential drugs for stroke were evaluated worldwide, but only $19(4 \%)$ successfully reached the market. ${ }^{19}$ Of the remaining candidates, approximately 300 were discontinued, 70 continued preclinical evaluation, and 40 were in clinical trials. Among drugs currently in clinical use, twothirds are used for thrombus dissolution (e.g., plasminogen activators, antithrombotic agents, platelet aggregation agents) and one-third for neuroprotection. Other neuroprotective, nonthrombolytic treatments that are used outside of the US include Ginkgo Mihuan, Lumbricus rubellus extract, fasudil, Cerebrolysin, citicoline, kallidinogenase, and edaravone..$^{19}$

\section{Nimodipine: A Calcium Channel Inhibitor}

Calcium channel inhibition with nimodipine, a 1,4-dihydrophyridine calcium channel antagonist and cerebral vasodilator, has been evaluated in a variety of preclinical ${ }^{64}$ and clinical randomized controlled trials (RCTs) in patients with stroke. Clinical evaluation involved the American Nimodipine Study, ${ }^{7}$ the TRUST Study, ${ }^{146}$ and the VENUS trial, ${ }^{63}$ among others. ${ }^{47,73,149}$ Two meta-analyses evaluating patients from both large and smaller ischemic stroke trials that assessed $>7500$ patients in total failed to find an overall benefit for patients. ${ }^{65,107}$ Subgroup analysis did show a benefit in neurological function in patients treated within 12 hours, but patients who received intravenous nimodipine showed worse outcomes. Criticism of these trials included treatment at 24-48 hours after stroke, which was beyond the therapeutic window, as well as inclusion criteria, outcome measures, and limited preclinical support for this treatment.

\section{Glutamate Receptor Inhibitors}

Among the agents assessed for an ability to reduce glutamate excitotoxicity, NMDA and AMPA receptor inhibitors have been evaluated in preclinical and clinical trials but have shown limited therapeutic benefit. 3,25,57,127,147,151 These results suggest that non-NMDA-mediated mechanisms are also important in neuronal excitotoxicity. ${ }^{69}$ Some non-NMDA excitotoxic candidates include acidsensing ion channel $1 \mathrm{a},{ }^{115}$ proton-sensitive cation channels ${ }^{83}$ and transient receptor potential channels. ${ }^{159}$

Glutamate, the main excitatory neurotransmitter, can result in excitotoxic neural injury during ischemia mediated by $\mathrm{Ca}^{2+}$ cell influx in a variety of neurological disorders. ${ }^{102}$ Preclinical trials extensively evaluated the noncompetitive NMDA antagonists MK-801/dizocilpine, dextromethorphan, and aptiganel. ${ }^{51,105}$ Phase I dose-escalation trials of dextrorphan trials involving clinical treatment within 48 hours of stroke showed significant side effects, including hallucinations, agitation, hypotension, and stupor or apnea at high doses. ${ }^{2}$ MK-801 was also associated with significant neuropsychological adverse effects. ${ }^{116} \mathrm{~A}$ Phase II/III RCT in 628 patients treated within 6 hours of stroke with high- or low-dose aptiganel did not achieve the primary outcome of modified Rankin Scale (mRS) score at 3 months. ${ }^{3}$ Furthermore, a higher 4-month mortality rate was seen in the aptiganel group (26\% vs $19 \%$ ), and the study was aborted. The competitive NMDA antagonist CGS-19755/selfotel was evaluated preclinically and clinically, ${ }^{106}$ but similar neuropsychological adverse events were reported, including agitation, hallucination, paranoia, and delirium. ${ }^{57}$ Two Phase III RCTs involving 567 subjects that evaluated selfotel administered within 6 hours of stroke were suspended because there seemed to be a higher mortality rate in the selfotel-treated group..$^{24,25}$

Glycine antagonism of the NMDA receptor by GV150526/gavestinel resulted in reduction of infarct size in preclinical models. ${ }^{16}$ Two Phase III RCTs, namely the Glycine Antagonist in Neuroprotection (GAIN) American Trial and the GAIN International Trial, of 1646 and 1804 subjects, respectively, were conducted. ${ }^{81}$ Treatment was given within 6 hours of ischemic stroke, but neither trial showed an improvement in the primary outcome of Barthel Index at 3 months. A subgroup analysis of 571 patients with hemorrhagic stroke also failed to demonstrate any benefit from treatment with gavestinel. ${ }^{58}$

AMPA receptor antagonists, such as ZK200755 and YM872/zonampanel, have been evaluated in preclinical and clinical models, with apparently poor results. ${ }^{38,51,142}$ In a Phase II RCT that was ultimately suspended after 61 patients were enrolled, ZK200755 showed worsening National Institutes of Health Stroke Scale (NIHSS) score 


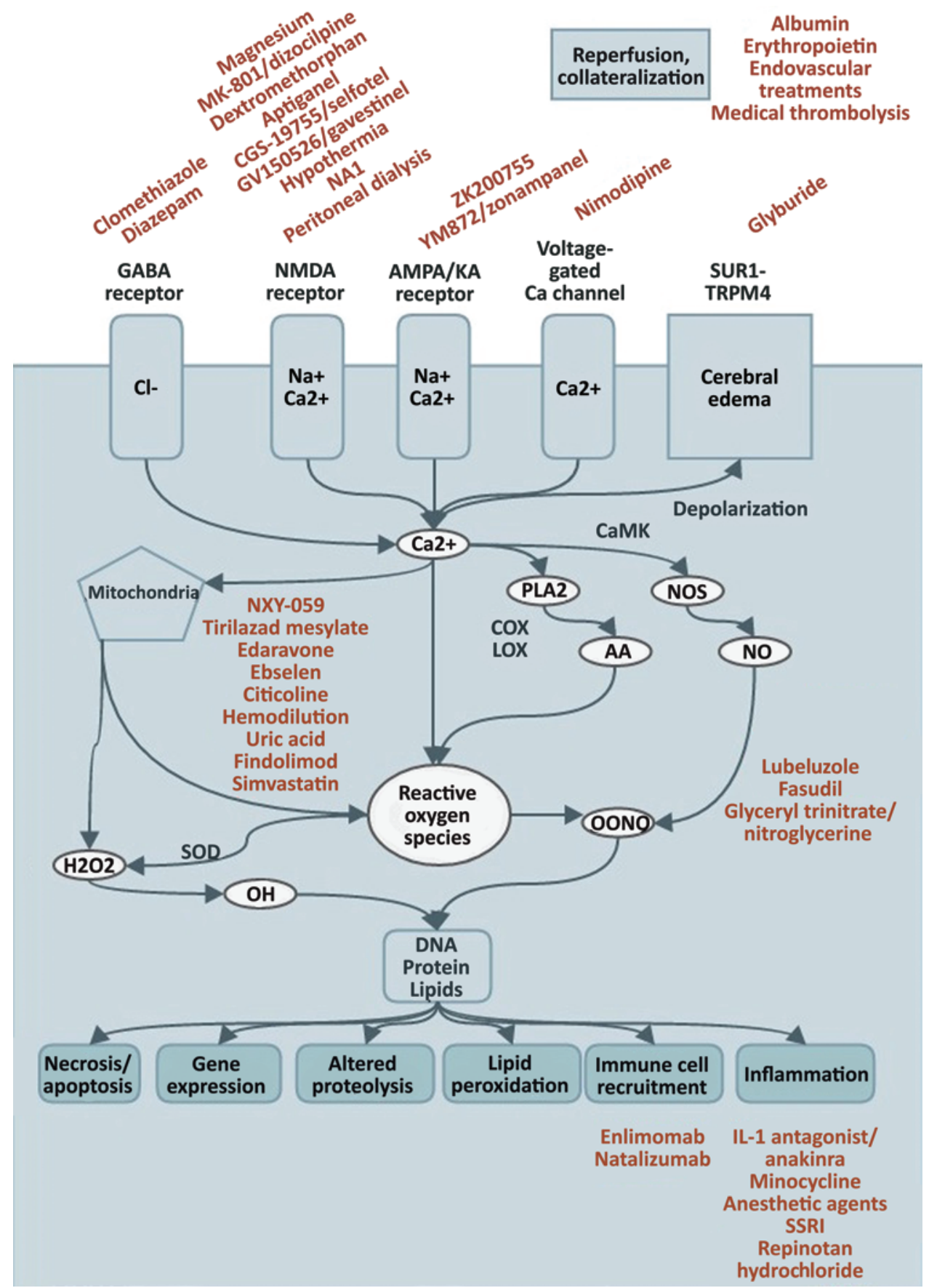

FIG. 1. Pathophysiology of ischemic stroke and neuroprotective strategies. The basic underlying pathology of ischemic stroke involves excitotoxicity and failure of cellular homeostatic functions, resulting in upregulation of calcium and free radicals. The end result involves cellular demise, maladaptive genetic expression, altered proteolysis, lipid peroxidation, recruitment of immune cells, and further inflammatory cascades. A variety of approaches (shown in red text) have attempted to target these various aspects. $\mathrm{AA}=$ arachidonic acid; CaMK = calcium/calmodulin-dependent protein kinase; $\mathrm{COX}=$ cyclooxygenase; $\mathrm{H}_{2} \mathrm{O}_{2}=$ hydrogen peroxide; $\mathrm{KA}=$ kainate; $\mathrm{LOX}=$ lipoxygenase; $\mathrm{NO}=$ nitric oxide; $\mathrm{NOS}=$ nitric oxide synthase; $\mathrm{OH}=$ hydroxide ion; $\mathrm{OONO}=$ peroxynitrite; PLA2 = phospholipase A2; SOD = superoxide dismutase; SSRI = selective serotonin-reuptake inhibitor.

and elevated S-100B biomarker. ${ }^{38}$ The AMPA Receptor Antagonist Treatment in Ischemic Stroke MRI Trial (ARTIST) and related ARTIST+ trial evaluated YM872/ zonampanel, but no peer-reviewed reports of the trial results were published. ${ }^{51} \mathrm{~A}$ recent meta-analysis of 7731 patients and 34 trials involving calcium channel antagonists also failed to show any benefit with nimodipine and in fact demonstrated worse outcome at higher doses. ${ }^{160}$

\section{$\gamma$-Aminobutyric Acid Agonists}

$\gamma$-Aminobutyric acid (GABA) agonists have widely been studied for their role in the major inhibitory neu- 
TABLE 2. Historical treatments in neuroprotection for ischemic stroke

\begin{tabular}{|c|c|c|}
\hline Treatment & Mechanism & References \\
\hline \multicolumn{3}{|l|}{ Calcium channel antagonist } \\
\hline Nimodipine & $\begin{array}{l}\text { 1,4-dihydrophyridine calcium channel antagonist \& } \\
\text { cerebral vasodilator }\end{array}$ & $\begin{array}{l}\text { American Nimodipine Study Group 1992, Trust Study } \\
\text { Group 1990, }{ }^{146} \text { Horn et al. 2001,63 Gelmers et al. 1988, }{ }^{47} \\
\text { Horn \& Limburg 2000, }{ }^{65} \text { Kaste et al. 1994, }{ }^{73} \text { Mohr et al. } \\
\text { 1994, }{ }^{107} \text { Wahlgren et al. } 1994^{149}\end{array}$ \\
\hline \multicolumn{3}{|l|}{ Glutamate antagonists } \\
\hline MK-801/dizocilpine & \multirow[t]{4}{*}{ NMDA antagonists, reduce glutamate excitotoxicity } & Olney $1994^{117}$ \\
\hline Dextromethorphan & & Albers et al. $1995^{2}$ \\
\hline Aptiganel & & Albers et al. $2001^{3}$ \\
\hline CGS-19755/selfotel & & Miyabe et al. $1997,{ }^{106}$ Davis et al. $1997,{ }^{24}$ Davis et al. $2000^{2}$ \\
\hline GV150526/gavestinel & $\begin{array}{l}\text { Glycine antagonist at the NMDA receptor, reduces } \\
\text { glutamate excitotoxicity }\end{array}$ & $\begin{array}{l}\text { Bordi et al. } 1997,,^{16} \text { Sacco et al. } 2001,,^{124} \text { Lees et al. } 2000,{ }^{81} \\
\quad \text { Haley et al. } 2005^{58}\end{array}$ \\
\hline ZK200755 & \multirow[t]{2}{*}{ AMPA receptor antagonists } & Elting et al. $2002^{38}$ \\
\hline YM872/zonampanel & & Ginsberg $2008^{51}$ \\
\hline Magnesium & $\begin{array}{l}\text { NMDA receptor voltage-dependent modulator that } \\
\text { reduces depolarization-induced excitotoxicity }\end{array}$ & $\begin{array}{l}\text { Yang et al. } 2000,{ }^{158} \text { Westermaier et al. } 2005,{ }^{155} \text { Meloni et al } \\
2006,{ }^{103} \text { Muir et al. } 2004^{110}\end{array}$ \\
\hline \multicolumn{3}{|l|}{ GABA agonists } \\
\hline Clomethiazole & \multirow[t]{2}{*}{ GABA agonists } & $\begin{array}{l}\text { Sydserff et al. } 1995,{ }^{140} \text { Marshall et al. } 1999,{ }^{98} \text { Wahlgren et } \\
\text { al. } 1999^{150}\end{array}$ \\
\hline Diazepam & & Lodder et al. $2006^{93}$ \\
\hline \multicolumn{3}{|l|}{ Antioxidants } \\
\hline $\begin{array}{l}\text { NXY-059 (disodium 4-[(tert- } \\
\text { butylimino)methyl] } \\
\text { benzene-1,3-disulfonate } \\
\mathrm{N} \text {-oxide) }\end{array}$ & Antioxidant agent & Kuroda et al. $1999,{ }^{79}$ Shuaib et al. $2007,{ }^{134}$ Ginsberg $2007^{50}$ \\
\hline Tirilazad mesylate & Lipid peroxidation inhibitor & $\begin{array}{l}\text { Sena et al. } 2007,{ }^{129} \text { Randomized Trial of Tirilazad Mesyl- } \\
\text { ate in Patients with Acute Stroke (RANTTAS) 1996,120 } \\
\text { Tirilazad International Steering Committee 2000144 }\end{array}$ \\
\hline $\begin{array}{l}\text { Edaravone/MCl-186/3-methyl- } \\
\text { 1-phenyl-2-pyrazolin-5-one }\end{array}$ & Lipid peroxidation inhibitor \& free radical scavenger & $\begin{array}{l}\text { Amemiya et al. } 2005,{ }^{6} \text { Edaravone Acute Infarction Study } \\
\text { Group 2003,35 Feng et al. } 2011,,^{41} \text { Shinohara et al. } \\
2009^{133}\end{array}$ \\
\hline $\begin{array}{l}\text { Ebselen/2-phenyl-1,2- } \\
\text { benzisoselenazol-3(2H)-one }\end{array}$ & $\begin{array}{l}\text { Selenium-based compound w/ glutathione peroxi- } \\
\text { dase-like activity }\end{array}$ & Namura et al. $2001^{113}$ \\
\hline Citicoline & $\begin{array}{l}\text { Cytidine 5-diphosphocholine mimicker that incorpo- } \\
\text { rates into neuronal membranes, causing increased } \\
\text { phospholipid synthesis \& decreased degrada- } \\
\text { tion, increased neurotransmitter levels, improved } \\
\text { ATPase function, \& decreased phospholipase A2 } \\
\text { activity \& reactive oxygen species generation }\end{array}$ & $\begin{array}{l}\text { Scandinavian Stroke Study Group 1988, }{ }^{126} \text { Italian Acute } \\
\text { Stroke Study Group 1988, }{ }^{72} \text { Amsterdam Stroke Study } \\
\text { 1992,55 Goslinga et al. 1992,55 Argentino et al. 1989, } \\
\text { Aichner et al. } 1998^{1}\end{array}$ \\
\hline Hemodilution & Reduces excitotoxicity \& metabolic demand & Kuroda et al. $1999,{ }^{79}$ Shuaib et al. $2007,{ }^{134}$ Ginsberg $2007^{50}$ \\
\hline \multicolumn{3}{|l|}{ Nitric oxide mediators } \\
\hline Lubeluzole & $\begin{array}{l}\text { 4-difluoro benzothiazole; thought to downregulate } \\
\text { glutamate-activated nitric oxide }\end{array}$ & $\begin{array}{l}\text { De Ryck et al. } 2000,{ }^{26} \text { Grotta } 1997,{ }^{, 6} \text { Diener } 1998,{ }^{30} \text { Diener } \\
\text { et al. } 2000,{ }^{31} \text { Gandolfo et al. } 2002^{45}\end{array}$ \\
\hline Fasudil & $\begin{array}{l}\text { Rho kinase inhibitor; regulates proliferation, apopto- } \\
\text { sis, \& cell motility; endothelial nitric oxide mediator }\end{array}$ & Shibuya et al. $2005,{ }^{132}$ Kubo et al. $2008,{ }^{78}$ Liao et al. $2007^{84}$ \\
\hline \multicolumn{3}{|l|}{ Immunomodulator } \\
\hline Enlimomab & $\begin{array}{l}\text { Intercellular adhesion molecule-1 monoclonal anti- } \\
\text { body inhibitor that reduces leukocyte adhesion }\end{array}$ & $\begin{array}{l}\text { Zhang et al. } 1995,{ }^{161} \text { Enlimomab Acute Stroke Trial Investi- } \\
\text { gators } 2001,{ }^{39} \text { Krams et al. } 2003^{77}\end{array}$ \\
\hline
\end{tabular}

rotransmitter pathways. One of the most extensively studied preclinical models of neuroprotection, clomethiazole, reduced ischemic territory after stroke by $58 \%$ in rats ${ }^{140}$ and $32 \%$ in small primates. ${ }^{98}$ The Clomethiazole Acute
Stroke Study (CLASS) evaluated 1360 patients randomly assigned to receive clomethiazole or placebo within 12 hours of stroke but did not find a difference in functional independence at 90 days. ${ }^{150}$ The subsequent randomized 
CLASS-I trial evaluated 1198 patients with ischemic stroke but did not achieve a difference in primary outcome of a Barthel Index $\geq 60$ at 90 days. Diazepam, another GABA agonist, was evaluated in a trial of 880 patients who had stroke but also failed to achieve a difference in primary outcome, which was independence on the RS at 3 months. ${ }^{93}$ A recent meta-analysis of 5 trials of GABA receptor agonists that included 2838 patients did not show a significant difference in outcome. ${ }^{89}$

\section{Magnesium as Treatment for Stroke}

Magnesium has been implicated for its importance in regulating the NMDA receptor by modulating voltagedependent channel depolarization excitotoxicity; it is used clinically for treatment of eclampsia. ${ }^{33}$ Preclinical models of magnesium showed reduction in rat infarct volumes in several trials, ${ }^{155,158}$ but these studies showed varying effects and confounders. ${ }^{103}$ Magnesium administration within 12 hours of stroke was evaluated in the clinical Intravenous Magnesium Efficacy in Stroke (IMAGES) Trial; the investigators found no difference in the rates of death or disability at 90 days in 2589 patients with acute stroke. ${ }^{109}$

\section{Antioxidant Agents}

A variety of antioxidant agents have been evaluated in ischemic stroke to reduce secondary damage. In preclinical trials of ischemia, the antioxidant NXY-059 (disodium 4-[(tert-butylimino)methyl] benzene-1,3-disulfonate $\mathrm{N}$-oxide) showed reduction of infarction by $77 \%$ in rodents $^{79}$ and $51 \%$ in primates. ${ }^{99}$ NXY-059 was evaluated in the Stroke-Acute Ischemic NXY Treatment I (SAINT I) trial with 1722 patients $^{82}$ and the SAINT II trial with 3306 patients. ${ }^{134}$ The SAINT I trial showed that NXY-059 improved the distribution of mRS scores compared with placebo, but did not affect the NIHSS scores or Barthel Index in patients. In addition, this clinical effect was small. The SAINT II trial did not show a difference between NXY059 and placebo. The trial demonstrated that the limited solubility and blood-brain barrier penetrance of NXY-059 were problematic. In addition, there was a long mean time of $>6$ hours until potential treatment. Overall, NXY-059 seemed to have reduced antioxidant potential compared with other compounds, such as vitamin E..$^{50}$

Tirilazad mesylate is a lipid peroxidation inhibitor that has been evaluated in preclinical trials involving a variety of neurological injuries, including stroke, where it reduced infarct volume by $29 \% .{ }^{129}$ Nevertheless, clinical trials have not demonstrated the same success. In fact, a meta-analysis of 6 trials of tirilazad in 1757 patients showed an increased risk of death or disability by $20 \% .^{144}$ The Randomized Trial of Tirilazad mesylate in patients with Acute Stroke (RANTTAS) was terminated early because an interim analysis of 556 patients showed no effect on outcome. ${ }^{120}$

Ebselen/2-phenyl-1,2-benzisoselenazol-3(2H)-one is a selenium compound with glutathione peroxidase-like activity that has shown reduction in infarct size in rodent models. ${ }^{112}$ A clinical trial of 302 patients showed a significant difference in primary outcome at 1 month but not at 3 months. ${ }^{157}$ Edaravone/MCI-186/3-methyl-1-phenyl2-pyrazolin-5-one is a lipid peroxidation inhibitor and free radical scavenger that has also shown benefit in preclinical models, with reduction in infarct volume by $30 \% .^{6}$ Patients in a Phase II clinical trial of edaravone did show improvement of mRS score at 3 months, ${ }^{35}$ and a meta-analysis of 3 trials (496 patients) showed overall improvement in the proportion of neurological improvement in patients treated with edaravone compared with control subjects (risk ratio 1.99, 95\% CI 1.6-2.49)..$^{41}$ However, the most recent RCT of edaravone in 401 patients failed to show a difference in $\mathrm{mRS}$ score $<1$ between edaravone and ozagrel (an antiplatelet thromboxane A2 synthesis inhibitor) (57.1\% vs $50.3 \%){ }^{133}$ Nevertheless, the culmination of these results was the basis for approval in 2001 of this treatment for acute stroke in Japan.

Citicoline, another class of compound resembling cytidine 5-diphosphocholine, has been evaluated extensively. It is incorporated into neuronal membranes where it causes increased phospholipid (e.g., phosphatidylcholine) synthesis and decreased degradation, increased neurotransmitter levels, improved ATPase function, and decreased phospholipase A2 activity and reactive oxygen species generation. ${ }^{128}$ Preclinical studies of citicoline treatment showed lower infarct volumes and improved animal behavior, but a variety of different treatment protocols have been evaluated with less success. ${ }^{68}$ Four clinical trials of citicoline have shown no differences in their primary outcome measures. ${ }^{19-21,153}$ Although a pooled analysis of 1372 participants with baseline NIHSS scores $\geq 8$ showed a statistically significant effect of citicoline on 3-month global outcome incorporating NIHSS, mRS, and Barthel Index scores at 3 months (25.2\% vs $20.2 \%$; $\mathrm{p}=0.0034)$, these trials were limited by multiple design flaws. ${ }^{23}$ The most recent International Citicoline Trial on Acute Stroke (ICTuS), which evaluated 2298 patients in a multicenter RCT, showed that global recovery was similar in both groups (OR 1.03; $\mathrm{p}=0.364) .{ }^{22}$ Finally, a recent meta-analysis of 10 randomized trials showed a higher rate of independence (OR 1.56, 95\% CI 1.12-2.16), but the effect was more limited than those of other treatments (e.g., TPA). ${ }^{130}$ Citicoline is in clinical use in a number of countries, including Argentina, Austria, Chile, Indonesia, Mexico, Portugal, Thailand, and Venezuela. ${ }^{18}$

\section{Nitric Oxide}

Lubeluzole, a 3,4-difluoro benzothiazole thought to downregulate glutamate-activated nitric oxide, was evaluated for its potential benefit in acute stroke. Preclinical models showed improved rodent tactile/proprioceptive behavior as well as reduced infarction volume when lubeluzole was administered within 5 minutes of stroke. ${ }^{26}$ Two subsequent trials evaluated the use of lubeluzole but showed no difference in primary outcome of mortality at 3 months..$^{31,56}$ The most recent trial in 1786 patients failed to show a difference in primary outcome of trichotomized Barthel Index at 3 months or in secondary outcomes. ${ }^{31} \mathrm{~A}$ meta-analysis of 5 trials and 3510 patients also failed to show a difference in mortality or dependence. ${ }^{45}$

\section{Immunoregulators for Stroke Therapy}

Evaluation of enlimomab, an intercellular adhesion molecule-1 monoclonal antibody inhibitor that reduces leukocyte adhesion, showed some promise in preclinical 
models ${ }^{161}$; however, in the Enlimomab Acute Stroke Trial (EAST) multicenter RCT of 625 patients, a difference in primary outcome of mRS score at 90 days showed a worsening of outcome in the treated group and a higher death rate. ${ }^{39}$ A similar approach using neutrophil activation blockade with the $\mathrm{CD} 11 \mathrm{~b} / \mathrm{CD} 11$ receptor inhibitor UK-279,276 was evaluated in 966 patients in the Acute Stroke Therapy by Inhibition of Neutrophils (ASTIN) tri$\mathrm{al}^{77}$; however, a lack of efficacy was seen and the trial was terminated early.

\section{Hemodilution as Treatment for Stroke}

Hemodilution was also evaluated as a treatment that could reduce excitotoxicity and metabolic demand during stroke. Several large trials, including the Scandinavian Stroke Study, ${ }^{126}$ the Italian Acute Stroke Study, ${ }^{72}$ the Amsterdam Stroke Study, ${ }^{55}$ the Italian Acute Stroke Study-Hemodilution (IASS-H) trial, ${ }^{9}$ and the Multicenter Austrian Hemodilution Trial, ${ }^{1}$ all failed to show benefits in a variety of primary outcomes.

\section{Rho Kinase Inhibitors}

Rho kinases play important roles in cytoskeletal structure and motility, proliferation, and apoptosis via a variety of downstream molecules. ${ }^{78,84}$ Rho kinase inhibitors have been shown to increase endothelial nitric oxide and to provide neuroprotection in a variety of preclinical models. ${ }^{78,121}$ A trial of fasudil in 160 patients with acute ischemic stroke showed significant improvement in neurological function $(\mathrm{p}=0.0013)$ and clinical outcome $(\mathrm{p}=0.0015) .{ }^{132}$ Currently, fasudil is approved for the treatment of stroke outside of the US.

\section{Challenges of Historical Approaches}

The historical role of many of these agents has been extensively described. ${ }^{51}$ As is apparent, various limitations in study design and translation of preclinical findings to clinical trials have affected these trials. ${ }^{18}$ Time to treatment is an important and difficult feature to control, but must be considered when translating laboratory findings to human trials. Adequate preclinical data to support larger clinical trials have also been lacking in some cases, including objective outcomes evaluating improvement in infarct size and neurobehavioral function, in addition to other trial design features. Drug bioavailability, therapeutic dosing with regard to side-effect profiles, and blood-brain barrier penetration have all limited translation to clinical use.

Importantly, these prior failures have helped the development of current preclinical and clinical approaches. The Stroke Therapy Academic Industry Roundtable (STAIR) criteria were one such approach in improving the development of guidelines for preclinical trials to reduce the number of failed clinical trials. ${ }^{42,139}$ The STAIR criteria that must be assessed include drug doses, timing of treatment, type of animal model used, monitoring of animals during injury and recovery, objective outcomes, type of stroke model used, sex differences, genetic background, and combined pharmacological agents (e.g., TPA and neuroprotective treatments). Further guidelines from a stakeholders meeting of the US National Institute of Neuro- logical Disorders and Stroke helped to identify additional areas for improvement of preclinical trials, including reproducibility and data reporting. ${ }^{80}$

\section{Recent and Future Clinical Trials}

These novel approaches have built off of prior work in neuroprotection to investigate new strategies aimed at the underlying inflammatory nature of stroke and prevention of secondary injury (Table 3).

\section{Hypothermia and Preservation of Cerebral Function Following Stroke}

Hypothermia has been evaluated as a potential method for preserving cerebral function after ischemic stroke because it reduces the activity of a variety of molecular factors associated with ischemic stroke. ${ }^{141}$ A meta-analysis of 60 animal models of ischemic stroke described various degrees and timings of hypothermia ${ }^{34}$ and different stroke induction models and lesion volumes. This study identified robust benefits of hypothermia in preclinical animal studies. Eleven of the studies analyzed in the meta-analysis with available data showed a combined treatment effect size of 50.7\% (95\% CI 37.9-63.5; p < 0.001); however, the meta-analysis acknowledged the disparity between the favorable preclinical trials and the generally negative results of clinical trials. A single-center, randomized clinical study of 25 patients demonstrated a better 6-month functional outcome on the NIHSS in patients treated with hypothermia and hemicraniectomy than in those with normothermia after hemicraniectomy. ${ }^{37}$ Lower rates of hemorrhagic transformation and malignant cerebral edema have also been reported in another series of 75 patients. ${ }^{62}$

Conversely, the Intravascular Cooling in the Treatment of Stroke (ICTuS) study was a Phase I trial evaluating the effect of inducing intravascular hypothermia within 6 hours of stroke onset. ${ }^{97}$ No difference in mortality or 90day outcome was seen for therapeutic hypothermia. The more recent ICTuS follow-up evaluated 120 subjects randomly assigned to hypothermia versus normothermia before the study was terminated. ${ }^{96}$ Several large meta-analyses evaluating hypothermia during brain surgery ${ }^{44}$ and cardiac surgery ${ }^{11}$ have been published. Whereas results for improved neurological function after brain surgery were nonsignificant, mild therapeutic hypothermia was concluded to improve neurological outcome after cardiac arrest but not during in-hospital cardiac arrest, asystole, or noncardiac causes of arrest. ${ }^{11,46}$ The EuroHYP1 trial is currently enrolling 1500 subjects to assess the primary outcome of improved 3-month functional outcome for hyperthermia versus normothermia. ${ }^{148}$

\section{Magnesium Treatment After Stroke}

The recent Field Administration of Stroke TherapyMagnesium (FAST-MAG) trial evaluated 1700 patients randomized to receive intravenous magnesium sulfate or placebo within 2 hours of stroke onset. ${ }^{125}$ Patients received a loading dose at the time of suspected acute stroke followed by 24-hour maintenance. Seventy-three percent of patients had ischemic stroke, $2.8 \%$ had intracranial hemorrhage, and $3.9 \%$ had stroke-mimicking symptoms. No 
TABLE 3. Current and future approaches in neuroprotection for ischemic stroke

\begin{tabular}{|c|c|c|}
\hline Treatment & Mechanism & References \\
\hline \multicolumn{3}{|l|}{ Excitotoxicity modulators } \\
\hline Hypothermia & $\begin{array}{l}\text { Various molecular mechanisms including reduction of } \\
\text { excitotoxicity }\end{array}$ & $\begin{array}{l}\text { Tahir \& Pabaney } 2016,{ }^{141} \text { Dumitrascu et al. } 2016,{ }^{34} \\
\text { Els et al. 2006, }{ }^{37} \text { Hong et al. } 2014,{ }^{62} \text { Lyden et al. } \\
2005,{ }^{97} \text { Lyden et al. } 2016,{ }^{96} \text { Galvin et al. } 2015,{ }^{44} \\
\text { Arrich et al. 2016, }{ }^{11} \text { van der Worp et al. } 20144^{148}\end{array}$ \\
\hline Magnesium & $\begin{array}{l}\text { Regulates NMDA receptor by modulating voltage-dependent } \\
\text { channel depolarization excitotoxicity }\end{array}$ & Saver et al. $2015^{125}$ \\
\hline NA1 & $\begin{array}{l}\text { Inhibitor of postsynaptic density-94 protein that links NMDA } \\
\text { receptors to excitotoxic signaling in neurons }\end{array}$ & Hill et al. $2012,{ }^{61}$ Liu et al. $2012^{90}$ \\
\hline Uric acid & Antioxidant & $\begin{array}{l}\text { Romanos et al. } 2007,{ }^{123} \text { Onetti et al. } 2015,{ }^{118} \text { Cham- } \\
\quad \text { orro et al. 2014, }{ }^{17} \text { Amaro et al. } 2016,{ }^{4} \text { Llull } 2015^{92}\end{array}$ \\
\hline Fingolimod & $\begin{array}{l}\text { Sphingosine-1-phosphate receptor target, reduces excitotox- } \\
\text { icity or hypoxia }\end{array}$ & Wei et al. $2011,{ }_{154}$ Fu et al. $2014^{43}$ \\
\hline Peritoneal dialysis & Clearance of glutamate & del Carmen Godino et al. $2013^{27}$ \\
\hline \multicolumn{3}{|l|}{ Anti-inflammatory agents } \\
\hline IL-1 antagonist/anakinra & Anti-inflammatory agent & Mulcahy et al. $2003^{11}$ \\
\hline Minocycline & Tetracycline antibiotic w/ anti-inflammatory effects & $\begin{array}{l}\text { Fagan et al. } 2010,,^{40} \text { Murata et al. } 2008,{ }^{112} \text { Kohler et } \\
\quad \text { al. } 2013,{ }^{76} \text { Amiri-Nikpour et al. } 2015^{8}\end{array}$ \\
\hline Anesthetic agents & & Ishida et al. $2014^{70}$ \\
\hline $\begin{array}{l}\text { Selective serotonin-reuptake } \\
\text { inhibitors }\end{array}$ & & Siepmann et al. $2015^{135}$ \\
\hline Repinotan hydrochloride & 5-HT1A agonist & Teal et al. $2009^{143}$ \\
\hline Simvastatin & HMG-CoA reductase inhibitor that reduces cholesterol levels & Montaner et al. $2016^{108}$ \\
\hline \multicolumn{3}{|l|}{ Reperfusion-targeted agents } \\
\hline Albumin & $\begin{array}{l}\text { Volume expander, reduces volume of infarction, reduces ce- } \\
\text { rebral edema, \& improves behavioral outcomes in animals }\end{array}$ & $\begin{array}{l}\text { Nimmagadda et al. } 2008,,^{114} \text { Park et al. 2008, }{ }^{119} \\
\text { Ginsberg et al. 2006, }{ }^{53} \text { Ginsberg et al. } 2011,{ }^{54} \\
\text { Ginsberg \& Hill } 2015^{52}\end{array}$ \\
\hline Erythropoietin & $\begin{array}{l}\text { Secretory molecule that increases red blood cell production } \\
\text { \& is used in the treatment of anemia }\end{array}$ & $\begin{array}{l}\text { Asadi et al. } 2013,{ }^{13} \text { Ehrenreich et al. } 2009,{ }^{36} \text { Lund } \\
\text { et al. } 2014{ }^{95}\end{array}$ \\
\hline \multicolumn{3}{|l|}{ Cerebral edema-targeting agent } \\
\hline Glyburide & Inhibitor of SUR1-TRPM4 to reduce cerebral edema & $\begin{array}{l}\text { Khanna et al. } 2014,,^{75} \text { Tosun et al. } 2013,{ }^{145} \text { Sheth et } \\
\text { al. 2014, }{ }^{131} \text { Sheth et al. 2016 }\end{array}$ \\
\hline \multicolumn{3}{|l|}{ Nitric oxide mediator } \\
\hline Glyceryl trinitrate/nitroglycerine & Nitric oxide donor & Bath et al. $2015^{14}$ \\
\hline \multicolumn{3}{|l|}{ Immunomodulator } \\
\hline Natalizumab & $\begin{array}{l}\text { CD49d antibody that targets a4-integrin \& reduces leukocyte } \\
\text { invasion }\end{array}$ & Liesz et al. $2011,{ }^{85}$ Llovera et al. $2015^{91}$ \\
\hline
\end{tabular}

HMG-CoA = 3-hydroxy-3-methylglutaryl coenzyme A.

significant shift in 90-day mRS score was seen after treatment with magnesium $(p=0.28)$. Secondary outcomes of mortality also did not differ between the magnesium and placebo groups ( $15.4 \%$ vs $15.5 \% ; \mathrm{p}=0.95)$.

\section{Albumin as a Neuroprotective Agent}

Several key trials have evaluated the potential for albumin to serve as a neuroprotective strategy in stroke. Preclinical models suggest that $25 \%$ albumin shows neuroprotective potential by decreasing the volume of infarction, reducing cerebral edema, and improving behavioral outcomes. ${ }^{113,118}$ The Phase I Albumin in Acute Stroke (ALIAS) trial demonstrated that $25 \%$ albumin within 16 hours of stroke onset was safe for use in 82 patients. ${ }^{53} \mathrm{~A}$ later Phase III ALIAS Part 1 trial in 434 patients who received $25 \%$ albumin within 5 hours of stroke demonstrated similar safety rates between groups but showed increased risk in patients $>83$ years of age, which has led to a restructuring of future trials of albumin. ${ }^{54}$ Recently published results of the Part 2 safety trial in 830 patients showed that endovascular thrombolysis, but not TPA, increased the rate of intracranial hemorrhage (risk ratio 2.14; $\mathrm{p}=0.025) .^{52}$

\section{Glyburide to Preserve Cerebral Function After Injury}

Since implication of the SUR1-TRPM4 channel in cerebral edema and hemorrhagic conversion of stroke, cerebral edema after ischemic stroke has been targeted with 
glyburide to preserve cerebral function after injury. ${ }^{75,145} \mathrm{~A}$ pilot trial in 10 patients helped demonstrate that a dose of 3 mg per day of intravenous glyburide was well tolerated. ${ }^{131}$ The GAMES-RP (glyburide on brain swelling after large hemispheric infarction) Phase II trial evaluated 86 patients with a primary outcome of mRS score 0-4 at 90 days in patients who did not undergo a decompressive craniectomy. ${ }^{130}$ No difference in primary composite outcome was seen, and the trial was terminated early because of loss of funding.

\section{Uric Acid}

Uric acid, a potent antioxidant that contains two-thirds of the plasma's total antioxidant capacity, was evaluated in several preclinical models. ${ }^{117,123}$ Combined uric acid and alteplase within 4.5 hours of stroke was evaluated in the Phase IIb/III URICO-ICTUS (Uric acid in patients with acute stroke) trial. ${ }^{17}$ A subsequent analysis of the URICOICTUS trial for early ischemic worsening, defined as an increase of $\geq 4$ points on the NIHSS within 72 hours, showed a significant decrease in early ischemic worsening in patients treated with uric acid (7 of 204 vs 18 of 200; $\mathrm{p}=0.01) .{ }^{4}$ Although the primary outcome of mRS score at 90 days was no different from that of control subjects, the incidence of early clinical worsening was lower and a greater number of patients with treatment reached full independence. Reduced infarct size was shown in specific subgroups, including women, patients with pretreatment hyperglycemia, and early recanalization., ${ }^{5,92}$

\section{Other Approaches}

The ENACT (Safety and efficacy of NA-1 in patients with iatrogenic stroke after endovascular aneurysm repair) trial evaluated intravenous NA-1, an inhibitor of postsynaptic density-94 protein that links NMDA receptors to excitotoxic signaling in neurons. Although preclinical trials showed benefit for NA-1, clinical trials failed to show reduction in infarction size..$^{61}$

Calcium channel antagonism with ginsenoside $\mathrm{Rd}$ has also been evaluated in an RCT during treatment within 72 hours of stroke, with improved functional recovery and without significant adverse events. ${ }^{90}$

The Efficacy of Nitric Oxide in Stroke (ENOS) trial evaluated glyceryl trinitrate or nitroglycerin, a nitric oxide donor, in the treatment of acute ischemic stroke. ${ }^{14}$ The ENOS trial did not show a difference in primary outcome. Preclinical trials showed that glyceryl trinitrate could reduce lesion size and increase cerebral perfusion. ${ }^{88} \mathrm{~A}$ subgroup analysis of 25 studies using a variety of nitric oxide donors in 273 animals treated within 6 hours of stroke showed improved functional outcome, reduced infarct volume, improved cerebral blood flow, and reduced mortality. 156

Fingolimod, which targets the sphingosine-1-phosphate receptor and reduces lymphocyte concentration and excitotoxicity or hypoxia, has been evaluated in preclinical and clinical trials. ${ }^{154}$ An open-label trial of fingolimod administered within 72 hours of stroke showed efficacy in limiting infarct size and improving disability. ${ }^{43}$

Peritoneal dialysis to reduce blood levels of glutamate has shown efficacy in a rodent model. ${ }^{27}$ Current trials are evaluating dialysis in acute stroke (EudraCT 2012000791-42).

Natalizumab is a CD49d antibody that targets $\alpha 4$-integrin and reduces leukocyte invasion. It has been shown in preclinical stroke models to reduce T-cell and neutrophil infiltration. ${ }^{85}$ In preclinical models, natalizumab also showed reduction in infarct size after stroke. ${ }^{11}$ The ACTION trial (NCT01955707) is currently evaluating this treatment in clinical settings, and preliminary results suggest that treatment did not reduce infarct volume at 5 days but improved the Stroke Clinical Impact-16 score and cognitive function at 90 days.

IL-1 antagonism, via recombinant IL-1Ra/anakinra, is another recently defined anti-inflammatory mechanism that is being evaluated in ischemic stroke. Animal models of IL-1 have shown reduced lesion size and cell death. ${ }^{111} \mathrm{~A}$ current Phase II trial is evaluating this treatment in clinical settings (ISRCTN74236229).

Minocycline, a tetracycline antibiotic with anti-inflammatory effects, showed good preclinical utility and was beneficial in a small pilot study, Minocycline to Improve Neurological Outcome in Stroke (MINOS). The results showed that minocycline was safe for use within 24 hours of stroke but demonstrated no improvement in disability at 90 days. ${ }^{40}$ Animal models have also shown improved cerebral protection during combined TPA and minocycline administration. ${ }^{112}$ Whereas an underpowered openlabel trial in 95 participants failed to show a difference in $\mathrm{mRS}$ score of $\leq 2$ at 90 days with treatment, ${ }^{76}$ another open-label trial evaluating minocycline $(200 \mathrm{mg}$ for 5 days) in 53 patients showed significantly better NIHSS scores at 90 days compared with control subjects (4 vs $7 ; \mathrm{p}=0.031) .{ }^{8}$ A larger RCT of minocycline with TPA is pending (ACTRN12611001053910).

Erythropoietin, a secretory molecule that increases red blood cell production and is used in the treatment of anemia, has been evaluated for use in treating ischemic stroke. A Phase II trial comparing 37 patients treated with erythropoietin and 43 patients who received placebo demonstrated a significant decrease in NIHSS score at 4 weeks for patients who were treated with erythropoietin (2.11 vs $6.05 ; \mathrm{p}=0.0001) .{ }^{14}$ A Phase III trial of 522 patients with middle cerebral artery stroke showed no favorable effect of erythropoietin on the primary outcome of Barthel Index at Day $90(\mathrm{p}=0.45) .{ }^{36}$ In addition, no difference in death rate (42 of 256 vs 24 of 266, OR 1.98, 95\% CI 1.16-3.38) was seen between the erythropoietin and placebo groups. A meta-analysis of high-dose erythropoietin for tissue protection that evaluated $26 \mathrm{RCTs}$ and 3176 patients failed to show a tissue-protective role..$^{95}$

Anesthetic agents have also been assessed for potential efficacy in preclinical and clinical models of tissue protection. ${ }^{70}$ A meta-analysis of selective serotonin-reuptake inhibitors involving 52 trials of 4060 patients suggested improvement of structure-function, neurogenesis, migration of cells into damaged areas, modulation of the neurohormonal system, and improved cerebral blood flow. ${ }^{125}$ The modified Randomized Exposure Controlled Trial (mRECT) evaluated 681 patients treated with TPA plus repinotan hydrochloride (a 5-HT1A serotonin agonist) or placebo. ${ }^{143}$ The primary outcome of response rate on 
Barthel Index was similar between the treated and control groups (127 of 342 vs 143 of $337 ; p=0.149$ ). High-dose simvastatin (40 mg) in combination with thrombolysis was assessed in the Stroke Treatment With Acute Reperfusion and Simvastatin (STARS) trial: ${ }^{108}$ there was no difference in the primary outcome of improved $\mathrm{mRS}$ score $\geq 2$ in a total of 104 patients randomly assigned to receive either simvastatin or placebo.

\section{Summary of Current and Future Clinical Approaches}

Overall, these approaches for neuroprotection in acute stroke aim to use known pathophysiological mechanisms of disease, such as excitatory inflammation, as well as novel approaches, such as reduction of SUR1-TRPM4-mediated cerebral edema. As of December 2016, the Internet Stroke Center listed 346 studies evaluating treatments in ischemic stroke, including 60 trials of neuroprotective agents. The publication of the results of these trials, whether findings are confirmatory or negative, will be important for the understanding of ischemic stroke and future therapeutic approaches.

\section{Integration With Endovascular Therapies}

Recent clinical trials supporting the use of endovascular treatment for acute ischemic stroke have redefined the potential applications of neuroprotective strategies. Key trials, including Multicenter Randomized Clinical Trial of Endovascular Treatment for Acute Ischemic Stroke in the Netherlands (MR CLEAN), Endovascular Treatment for Small Core and Proximal Occlusion Ischemic Stroke (ESCAPE), Extending the Time for Thrombolysis in Emergency Neurological Deficits-Intra-Arterial (EXTEND-IA), Solitaire With the Intention For Thrombectomy as Primary Endovascular Treatment (SWIFTPRIME), and Endovascular Revascularization With Solitaire Device Versus Best Medical Therapy in Anterior Circulation Stroke Within 8 Hours (REVASCAT), have improved our understanding of the benefits of early endovascular intervention in ischemic stroke. ${ }^{49,122}$

Protection of the ischemic penumbra (areas of tissue with neurological dysfunction due to reduced blood supply but maintained metabolism and potential for recovery) is the critical approach in endovascular treatments. ${ }^{66}$ Phases of infarct progression include the ischemic core $(20 \%$ less than normal flow), the ischemic penumbra $(25 \%-50 \%$ of normal flow), and less ischemic/oligemic tissue with variable apoptosis. ${ }^{60}$ It is the penumbra and oligemic areas that could potentially benefit from neuroprotective strategies by improving collateral flow and protecting viable tissue.

To work synergistically with current reperfusion strategies, approaches would need to: 1) involve early intervention (within the first 4-6 hours of stroke), 2) show preclinical evidence of efficacy and adequate therapeutic levels after administration with manageable side effects, and 3) have adequate trials to evaluate use. ${ }^{49}$ Current endovascular therapies have shown improved recanalization rates compared with first-generation methods alone. In addition, improved time to treatment and the formation of dedicated stroke centers have led to a potential resurgence of neuroprotective studies. Various experimental therapies may be useful in early revascularization. Oxidative stress-reducing agents or treatments that improve cerebral perfusion are potential approaches. These treatments may have failed initial clinical trials if adequate tissue perfusion and drug delivery were hindered by the initial ischemic stroke. In addition, direct catheter delivery of these agents may be a method of rapid and targeted drug delivery.

\section{Conclusions}

Although numerous and varied clinical approaches have been evaluated for use in neuroprotection with ischemic stroke, few treatments have entered clinical practice. As additional guidelines for the translation of preclinical to clinical treatment have been defined, improved collaboration and study networks have arisen as a result of previously examined treatment approaches. Assessment of future treatments by collaborations among multiple institutions and partnerships with patient-advocacy groups may allow more rapid identification of potentially beneficial agents.

The use of combined therapeutic options, such as the combination of TPA with other neuroprotective treatments, should continue to be an area of exploration. In fact, treatment to help reduce hemorrhagic conversion of ischemic stroke could potentially make TPA a safer therapy. Newer findings showing the benefit of thrombolytic reperfusion strategies have also created new opportunities for combined treatments. Because of the rapid rise in the number of stroke centers, telestroke sites, and even mobile telestroke services, additional pharmacological treatments can be rapidly delivered to patients and may change the paradigm for treatment. Thus, although past trials of neuroprotective agents have been limited, the future is promising.

\section{References}

1. Aichner FT, Fazekas F, Brainin M, Pölz W, Mamoli B, Zeiler K: Hypervolemic hemodilution in acute ischemic stroke: the Multicenter Austrian Hemodilution Stroke Trial (MAHST). Stroke 29:743-749, 1998

2. Albers GW, Atkinson RP, Kelley RE, Rosenbaum DM: Safety, tolerability, and pharmacokinetics of the N-methylD-aspartate antagonist dextrorphan in patients with acute stroke. Stroke 26:254-258, 1995

3. Albers GW, Goldstein LB, Hall D, Lesko LM: Aptiganel hydrochloride in acute ischemic stroke: a randomized controlled trial. JAMA 286:2673-2682, 2001

4. Amaro S, Laredo C, Renú A, Llull L, Rudilosso S, Obach $\mathrm{V}$, et al: Uric acid therapy prevents early ischemic stroke progression: a tertiary analysis of the URICO-ICTUS Trial (efficacy study of combined treatment with uric acid and r-tPA in acute ischemic stroke). Stroke 47:2874-2876, 2016

5. Amaro S, Llull L, Renú A, Laredo C, Perez B, Vila E, et al: Uric acid improves glucose-driven oxidative stress in human ischemic stroke. Ann Neurol 77:775-783, 2015

6. Amemiya S, Kamiya T, Nito C, Inaba T, Kato K, Ueda M, et al: Anti-apoptotic and neuroprotective effects of edaravone following transient focal ischemia in rats. Eur $\mathbf{J}$ Pharmacol 516: 125-130, 2005

7. American Nimodipine Study Group: Clinical trial of nimodipine in acute ischemic stroke. Stroke 23:3-8, 1992

8. Amiri-Nikpour MR, Nazarbaghi S, Hamdi-Holasou M, Rezaei Y: An open-label evaluator-blinded clinical study 
of minocycline neuroprotection in ischemic stroke: genderdependent effect. Acta Neurol Scand 131:45-50, 2015

9. Argentino C, Sacchetti ML, Toni D, Savoini G, D'Arcangelo E, Erminio F, et al: GM1 ganglioside therapy in acute ischemic stroke. Italian Acute Stroke StudyHemodilution + Drug. Stroke 20:1143-1149, 1989

10. Aronowski J, Zhao X: Molecular pathophysiology of cerebral hemorrhage: secondary brain injury. Stroke 42:17811786, 2011

11. Arrich J, Holzer M, Havel C, Müllner M, Herkner H: Hypothermia for neuroprotection in adults after cardiopulmonary resuscitation. Cochrane Database Syst Rev 2:CD004128, 2016

12. Arumugam TV, Granger DN, Mattson MP: Stroke and T-cells. Neuromolecular Med 7:229-242, 2005

13. Asadi B, Askari GR, Khorvash F, Bagherpur A, Mehrabi F, Karimi M, et al: Neuroprotective effects of erythropoietin in acute ischemic stroke. Int J Prev Med 4 (Suppl 2):S306S312, 2013

14. Bath PM, Woodhouse L, Scutt P, Krishnan K, Wardlaw JM, Bereczki D, et al: Efficacy of nitric oxide, with or without continuing antihypertensive treatment, for management of high blood pressure in acute stroke (ENOS): a partialfactorial randomised controlled trial. Lancet 385:617-628, 2015

15. Bordi F, Pietra C, Ziviani L, Reggiani A: The glycine antagonist GV150526 protects somatosensory evoked potentials and reduces the infarct area in the MCAo model of focal ischemia in the rat. Exp Neurol 145:425-433, 1997

16. Broughton BR, Reutens DC, Sobey CG: Apoptotic mechanisms after cerebral ischemia. Stroke 40:e331-e339, 2009

17. Chamorro A, Amaro S, Castellanos M, Segura T, Arenillas J, Martí-Fábregas J, et al: Safety and efficacy of uric acid in patients with acute stroke (URICO-ICTUS): a randomised, double-blind phase 2b/3 trial. Lancet Neurol 13:453-460, 2014

18. Chen X, Wang K: The fate of medications evaluated for ischemic stroke pharmacotherapy over the period 1995 2015. Acta Pharm Sin B 6:522-530, 2016

19. Clark WM, Warach SJ, Pettigrew LC, Gammans RE, Sabounjian LA: A randomized dose-response trial of citicoline in acute ischemic stroke patients. Neurology 49:671678,1997

20. Clark WM, Wechsler LR, Sabounjian LA, Schwiderski UE: A phase III randomized efficacy trial of $2000 \mathrm{mg}$ citicoline in acute ischemic stroke patients. Neurology 57:1595-1602, 2001

21. Clark WM, Williams BJ, Selzer KA, Zweifler RM, Sabounjian LA, Gammans RE: A randomized efficacy trial of citicoline in patients with acute ischemic stroke. Stroke 30:2592-2597, 1999

22. Dávalos A, Alvarez-Sabín J, Castillo J, Díez-Tejedor E, Ferro J, Martínez-Vila E, et al: Citicoline in the treatment of acute ischaemic stroke: an international, randomised, multicentre, placebo-controlled study (ICTUS trial). Lancet 380:349-357, 2012

23. Dávalos A, Castillo J, Alvarez-Sabín J, Secades JJ, Mercadal J, López S, et al: Oral citicoline in acute ischemic stroke: an individual patient data pooling analysis of clinical trials. Stroke 33:2850-2857, 2002

24. Davis SM, Albers GW, Diener HC, Lees KR, Norris J: Termination of acute stroke studies involving selfotel treatment. Lancet 349:32, 1997

25. Davis SM, Lees KR, Albers GW, Diener HC, Markabi S, Karlsson G, et al: Selfotel in acute ischemic stroke: possible neurotoxic effects of an NMDA antagonist. Stroke 31:347354,2000

26. De Ryck M, Verhoye M, Van der Linden AM: Diffusionweighted MRI of infarct growth in a rat photochemical stroke model: effect of lubeluzole. Neuropharmacology 39:691-702, 2000

27. del Carmen Godino M, Romera VG, Sánchez-Tomero JA, Pacheco J, Canals S, Lerma J, et al: Amelioration of ischemic brain damage by peritoneal dialysis. J Clin Invest 123:4359-4363, 2013

28. del Zoppo GJ, Hallenbeck JM: Advances in the vascular pathophysiology of ischemic stroke. Thromb Res 98:7381,2000

29. del Zoppo GJ, Milner R, Mabuchi T, Hung S, Wang X, Berg GI, et al: Microglial activation and matrix protease generation during focal cerebral ischemia. Stroke 38 (2 Suppl):646-651, 2007

30. Diener HC: Multinational randomised controlled trial of lubeluzole in acute ischaemic stroke. Cerebrovasc Dis 8:172-181, 1998

31. Diener HC, Cortens M, Ford G, Grotta J, Hacke W, Kaste $\mathrm{M}$, et al: Lubeluzole in acute ischemic stroke treatment: A double-blind study with an 8-hour inclusion window comparing a 10-mg daily dose of lubeluzole with placebo. Stroke 31:2543-2551, 2000

32. Dirnagl U, Iadecola C, Moskowitz MA: Pathobiology of ischaemic stroke: an integrated view. Trends Neurosci 22:391-397, 1999

33. Duley L, Gülmezoglu AM, Henderson-Smart DJ, Chou D: Magnesium sulphate and other anticonvulsants for women with pre-eclampsia. Cochrane Database Syst Rev (11):CD000025, 2010

34. Dumitrascu OM, Lamb J, Lyden PD: Still cooling after all these years: Meta-analysis of pre-clinical trials of therapeutic hypothermia for acute ischemic stroke. J Cereb Blood Flow Metab 36:1157-1164, 2016

35. Edaravone Acute Infarction Study Group: Effect of a novel free radical scavenger, edaravone (MCI-186), on acute brain infarction. Randomized, placebo-controlled, double-blind study at multicenters. Cerebrovasc Dis 15:222-229, 2003

36. Ehrenreich H, Weissenborn K, Prange H, Schneider D, Weimar C, Wartenberg K, et al: Recombinant human erythropoietin in the treatment of acute ischemic stroke. Stroke 40:e647-e656, 2009

37. Els T, Oehm E, Voigt S, Klisch J, Hetzel A, Kassubek J: Safety and therapeutical benefit of hemicraniectomy combined with mild hypothermia in comparison with hemicraniectomy alone in patients with malignant ischemic stroke. Cerebrovasc Dis 21:79-85, 2006

38. Elting JW, Sulter GA, Kaste M, Lees KR, Diener HC, Hommel M, et al: AMPA antagonist ZK200775 in patients with acute ischemic stroke: possible glial cell toxicity detected by monitoring of S-100B serum levels. Stroke 33:2813-2818, 2002

39. Enlimomab Acute Stroke Trial Investigators: Use of anti-ICAM-1 therapy in ischemic stroke: results of the Enlimomab Acute Stroke Trial. Neurology 57:1428-1434, 2001

40. Fagan SC, Waller JL, Nichols FT, Edwards DJ, Pettigrew LC, Clark WM, et al: Minocycline to improve neurologic outcome in stroke (MINOS): a dose-finding study. Stroke 41:2283-2287, 2010

41. Feng S, Yang Q, Liu M, Li W, Yuan W, Zhang S, et al: Edaravone for acute ischaemic stroke. Cochrane Database Syst Rev (12):CD007230, 2011

42. Fraser JF: Standardisation of research strategies in acute ischaemic stroke. Lancet Neurol 15:784-785, 2016

43. Fu Y, Zhang N, Ren L, Yan Y, Sun N, Li YJ, et al: Impact of an immune modulator fingolimod on acute ischemic stroke. Proc Natl Acad Sci U S A 111:18315-18320, 2014

44. Galvin IM, Levy R, Boyd JG, Day AG, Wallace MC: Cooling for cerebral protection during brain surgery. Cochrane Database Syst Rev 1:CD006638, 2015 
45. Gandolfo C, Sandercock P, Conti M: Lubeluzole for acute ischaemic stroke. Cochrane Database Syst Rev (1):CD001924, 2002

46. Gelderblom M, Leypoldt F, Steinbach K, Behrens D, Choe CU, Siler DA, et al: Temporal and spatial dynamics of cerebral immune cell accumulation in stroke. Stroke 40:18491857,2009

47. Gelmers HJ, Gorter K, de Weerdt CJ, Wiezer HJ: A controlled trial of nimodipine in acute ischemic stroke. $\mathbf{N ~ E n g l ~}$ J Med 318:203-207, 1988

48. Ginsberg MD: Current status of neuroprotection for cerebral ischemia: synoptic overview. Stroke 40 (3 Suppl):S111S114, 2009

49. Ginsberg MD: Expanding the concept of neuroprotection for acute ischemic stroke: the pivotal roles of reperfusion and the collateral circulation. Prog Neurobiol 145-146:46-77, 2016

50. Ginsberg MD: Life after cerovive: a personal perspective on ischemic neuroprotection in the post-NXY-059 era. Stroke 38: 1967-1972, 2007

51. Ginsberg MD: Neuroprotection for ischemic stroke: past, present and future. Neuropharmacology 55:363-389, 2008

52. Ginsberg MD, Hill MD: Symptomatic intracranial hemorrhage in the ALIAS Multicenter Trial: relationship to endovascular thrombolytic therapy. Int J Stroke 10:494-500, 2015

53. Ginsberg MD, Hill MD, Palesch YY, Ryckborst KJ, Tamariz D: The ALIAS Pilot Trial: a dose-escalation and safety study of albumin therapy for acute ischemic strokeI: Physiological responses and safety results. Stroke 37:2100-2106, 2006

54. Ginsberg MD, Palesch YY, Martin RH, Hill MD, Moy CS, Waldman BD, et al: The albumin in acute stroke (ALIAS) multicenter clinical trial: safety analysis of part 1 and rationale and design of part 2. Stroke 42:119-127, 2011

55. Goslinga H, Eijzenbach V, Heuvelmans JH, van der Laan de Vries E, Melis VM, Schmid-Schönbein H, et al: Customtailored hemodilution with albumin and crystalloids in acute ischemic stroke. Stroke 23:181-188, 1992

56. Grotta J: Lubeluzole treatment of acute ischemic stroke. Stroke 28:2338-2346, 1997

57. Grotta J, Clark W, Coull B, Pettigrew LC, Mackay B, Goldstein LB, et al: Safety and tolerability of the glutamate antagonist CGS 19755 (Selfotel) in patients with acute ischemic stroke. Results of a phase IIa randomized trial. Stroke 26:602-605, 1995

58. Haley EC Jr, Thompson JL, Levin B, Davis S, Lees KR, Pittman JG, et al: Gavestinel does not improve outcome after acute intracerebral hemorrhage: an analysis from the GAIN International and GAIN Americas studies. Stroke 36: 1006-1010, 2005

59. Hall ED: Inhibition of lipid peroxidation in central nervous system trauma and ischemia. J Neurol Sci 134 Suppl:7983, 1995

60. Heiss WD: The ischemic penumbra: correlates in imaging and implications for treatment of ischemic stroke. Cerebrovasc Dis 32:307-320, 2011

61. Hill MD, Martin RH, Mikulis D, Wong JH, Silver FL, Terbrugge KG, et al: Safety and efficacy of NA-1 in patients with iatrogenic stroke after endovascular aneurysm repair (ENACT): a phase 2, randomised, double-blind, placebo-controlled trial. Lancet Neurol 11:942-950, 2012

62. Hong JM, Lee JS, Song HJ, Jeong HS, Choi HA, Lee K: Therapeutic hypothermia after recanalization in patients with acute ischemic stroke. Stroke 45:134-140, 2014 (Erratum in Stroke 45:e12, 2014)

63. Horn J, de Haan RJ, Vermeulen M, Limburg M: Very Early Nimodipine Use in Stroke (VENUS): a randomized, doubleblind, placebo-controlled trial. Stroke 32:461-465, 2001
64. Horn J, de Haan RJ, Vermeulen M, Luiten PG, Limburg M: Nimodipine in animal model experiments of focal cerebral ischemia: a systematic review. Stroke 32:2433-2438, 2001

65. Horn J, Limburg M: Calcium antagonists for acute ischemic stroke. Cochrane Database Syst Rev (2):CD001928, 2000

66. Hossmann KA: Viability thresholds and the penumbra of focal ischemia. Ann Neurol 36:557-565, 1994

67. Hudome S, Palmer C, Roberts RL, Mauger D, Housman $\mathrm{C}$, Towfighi $\mathrm{J}$ : The role of neutrophils in the production of hypoxic-ischemic brain injury in the neonatal rat. Pediatr Res 41:607-616, 1997

68. Hurtado O, Cárdenas A, Pradillo JM, Morales JR, Ortego F, Sobrino T, et al: A chronic treatment with CDP-choline improves functional recovery and increases neuronal plasticity after experimental stroke. Neurobiol Dis 26:105-111, 2007

69. Ikonomidou C, Turski L: Why did NMDA receptor antagonists fail clinical trials for stroke and traumatic brain injury? Lancet Neurol 1:383-386, 2002

70. Ishida K, Berger M, Nadler J, Warner DS: Anesthetic neuroprotection: antecedents and an appraisal of preclinical and clinical data quality. Curr Pharm Des 20:5751-5765, 2014

71. Ishikawa M, Zhang JH, Nanda A, Granger DN: Inflammatory responses to ischemia and reperfusion in the cerebral microcirculation. Front Biosci 9:1339-1347, 2004

72. Italian Acute Stroke Study Group: Haemodilution in acute stroke: results of the Italian haemodilution trial. Lancet 1:318-321, 1988

73. Kaste M, Fogelholm R, Erilä T, Palomäki H, Murros K, Rissanen A, et al: A randomized, double-blind, placebocontrolled trial of nimodipine in acute ischemic hemispheric stroke. Stroke 25:1348-1353, 1994

74. Kernan WN, Ovbiagele B, Black HR, Bravata DM, Chimowitz MI, Ezekowitz MD, et al: Guidelines for the prevention of stroke in patients with stroke and transient ischemic attack: a guideline for healthcare professionals from the American Heart Association/American Stroke Association. Stroke 45:2160-2236, 2014

75. Khanna A, Walcott BP, Kahle KT, Simard JM: Effect of glibenclamide on the prevention of secondary brain injury following ischemic stroke in humans. Neurosurg Focus 36(1):E11, 2014

76. Kohler E, Prentice DA, Bates TR, Hankey GJ, Claxton $A$, van Heerden $J$, et al: Intravenous minocycline in acute stroke: a randomized, controlled pilot study and meta-analysis. Stroke 44:2493-2499, 2013

77. Krams M, Lees KR, Hacke W, Grieve AP, Orgogozo JM, Ford GA: Acute Stroke Therapy by Inhibition of Neutrophils (ASTIN): an adaptive dose-response study of UK-279,276 in acute ischemic stroke. Stroke 34:25432548, 2003

78. Kubo T, Yamaguchi A, Iwata N, Yamashita T: The therapeutic effects of Rho-ROCK inhibitors on CNS disorders. Ther Clin Risk Manag 4:605-615, 2008

79. Kuroda S, Tsuchidate R, Smith ML, Maples KR, Siesjö BK: Neuroprotective effects of a novel nitrone, NXY-059, after transient focal cerebral ischemia in the rat. J Cereb Blood Flow Metab 19:778-787, 1999

80. Landis SC, Amara SG, Asadullah K, Austin CP, Blumenstein R, Bradley EW, et al: A call for transparent reporting to optimize the predictive value of preclinical research. Nature 490:187-191, 2012

81. Lees KR, Asplund K, Carolei A, Davis SM, Diener HC, Kaste M, et al: Glycine antagonist (gavestinel) in neuroprotection (GAIN International) in patients with acute stroke: a randomised controlled trial. Lancet 355:1949-1954, 2000

82. Lees KR, Zivin JA, Ashwood T, Davalos A, Davis SM, Diener HC, et al: NXY-059 for acute ischemic stroke. $\mathbf{N}$ Engl J Med 354:588-600, 2006 
83. Leng T, Shi Y, Xiong ZG, Sun D: Proton-sensitive cation channels and ion exchangers in ischemic brain injury: new therapeutic targets for stroke? Prog Neurobiol 115:189209, 2014

84. Liao JK, Seto M, Noma K: Rho kinase (ROCK) inhibitors. J Cardiovasc Pharmacol 50:17-24, 2007

85. Liesz A, Zhou W, Mracskó É, Karcher S, Bauer H, Schwarting S, et al: Inhibition of lymphocyte trafficking shields the brain against deleterious neuroinflammation after stroke. Brain 134:704-720, 2011

86. Lipton P: Ischemic cell death in brain neurons. Physiol Rev 79:1431-1568, 1999

87. Lipton SA, Rosenberg PA: Excitatory amino acids as a final common pathway for neurologic disorders. N Engl J Med 330:613-622, 1994

88. Lisi M, Oelze M, Dragoni S, Liuni A, Steven S, Luca MC, et al: Chronic protection against ischemia and reperfusioninduced endothelial dysfunction during therapy with different organic nitrates. Clin Res Cardiol 101:453-459, 2012

89. Liu J, Wang LN, Ma X, Ji X: Gamma aminobutyric acid (GABA) receptor agonists for acute stroke. Cochrane Database Syst Rev 10:CD009622, 2016

90. Liu X, Wang L, Wen A, Yang J, Yan Y, Song Y, et al: Ginsenoside-Rd improves outcome of acute ischaemic stroke - a randomized, double-blind, placebo-controlled, multicenter trial. Eur J Neurol 19:855-863, 2012

91. Llovera G, Hofmann K, Roth S, Salas-Pérdomo A, FerrerFerrer M, Perego C, et al: Results of a preclinical randomized controlled multicenter trial (pRCT): Anti-CD49d treatment for acute brain ischemia. Sci Transl Med 7:299ra121, 2015

92. Llull L, Laredo C, Renú A, Pérez B, Vila E, Obach V, et al: Uric acid therapy improves clinical outcome in women with acute ischemic stroke. Stroke 46:2162-2167, 2015

93. Lodder J, van Raak L, Hilton A, Hardy E, Kessels A: Diazepam to improve acute stroke outcome: results of the early GABA-ergic activation study in stroke trial. A randomized double-blind placebo-controlled trial. Cerebrovasc Dis 21: 120-127, 2006

94. Love S: Oxidative stress in brain ischemia. Brain Pathol 9:119-131, 1999

95. Lund A, Lundby C, Olsen NV: High-dose erythropoietin for tissue protection. Eur J Clin Invest 44:1230-1238, 2014

96. Lyden P, Hemmen T, Grotta J, Rapp K, Ernstrom $\mathrm{K}$, Rzesiewicz T, et al: Results of the ICTuS 2 Trial (Intravascular Cooling in the Treatment of Stroke 2). Stroke 47:2888-2895, 2016

97. Lyden PD, Allgren RL, Ng K, Akins P, Meyer B, Al-Sanani F, et al: Intravascular Cooling in the Treatment of Stroke (ICTuS): early clinical experience. J Stroke Cerebrovasc Dis 14:107-114, 2005

98. Marshall JW, Cross AJ, Ridley RM: Functional benefit from clomethiazole treatment after focal cerebral ischemia in a nonhuman primate species. Exp Neurol 156:121-129, 1999

99. Marshall JW, Duffin KJ, Green AR, Ridley RM: NXY059, a free radical-trapping agent, substantially lessens the functional disability resulting from cerebral ischemia in a primate species. Stroke 32:190-198, 2001

100. Matsuo Y, Onodera H, Shiga Y, Nakamura M, Ninomiya M, Kihara T, et al: Correlation between myeloperoxidasequantified neutrophil accumulation and ischemic brain injury in the rat. Effects of neutrophil depletion. Stroke 25:1469-1475, 1994

101. Mattson MP: Roles of the lipid peroxidation product 4-hydroxynonenal in obesity, the metabolic syndrome, and associated vascular and neurodegenerative disorders. Exp Gerontol 44:625-633, 2009

102. Meldrum BS: Glutamate as a neurotransmitter in the brain: review of physiology and pathology. J Nutr 130 (4S Suppl): 1007S-1015S, 2000

103. Meloni BP, Zhu H, Knuckey NW: Is magnesium neuroprotective following global and focal cerebral ischaemia? A review of published studies. Magnes Res 19:123-137, 2006

104. Mergenthaler P, Dirnagl U, Meisel A: Pathophysiology of stroke: lessons from animal models. Metab Brain Dis 19:151-167, 2004

105. Minematsu K, Fisher M, Li L, Sotak CH: Diffusion and perfusion magnetic resonance imaging studies to evaluate a noncompetitive N-methyl-D-aspartate antagonist and reperfusion in experimental stroke in rats. Stroke 24:2074-2081, 1993

106. Miyabe M, Kirsch JR, Nishikawa T, Koehler RC, Traystman RJ: Comparative analysis of brain protection by $\mathrm{N}$-methyl-D-aspartate receptor antagonists after transient focal ischemia in cats. Crit Care Med 25:1037-1043, 1997

107. Mohr JP, Orgogozo JM, Harrison MJG, Hennerici M, Wahlgren NG, Gelmers JH, et al: Meta-analysis of oral nimodipine trials in acute ischemic stroke. Cerebrovasc Dis 4:197-203, 1994

108. Montaner J, Bustamante A, García-Matas S, MartínezZabaleta M, Jiménez C, de la Torre J, et al: Combination of thrombolysis and statins in acute stroke is safe: results of the STARS Randomized Trial (Stroke Treatment with Acute Reperfusion and Simvastatin). Stroke 47:2870-2873, 2016

109. Mozaffarian D, Benjamin EJ, Go AS, Arnett DK, Blaha MJ, Cushman M, et al: Heart disease and stroke statistics - 2016 update: a report from the American Heart Association. Circulation 133:e38-e360, 2016

110. Muir KW, Lees KR, Ford I, Davis S: Magnesium for acute stroke (Intravenous Magnesium Efficacy in Stroke trial): randomised controlled trial. Lancet 363:439-445, 2004

111. Mulcahy NJ, Ross J, Rothwell NJ, Loddick SA: Delayed administration of interleukin-1 receptor antagonist protects against transient cerebral ischaemia in the rat. $\mathbf{B r} \mathbf{J}$ Pharmacol 140:471-476, 2003

112. Murata Y, Rosell A, Scannevin RH, Rhodes KJ, Wang X, Lo EH: Extension of the thrombolytic time window with minocycline in experimental stroke. Stroke 39:3372-3377, 2008

113. Namura S, Nagata I, Takami S, Masayasu H, Kikuchi H: Ebselen reduces cytochrome c release from mitochondria and subsequent DNA fragmentation after transient focal cerebral ischemia in mice. Stroke 32:1906-1911, 2001

114. Nimmagadda A, Park HP, Prado R, Ginsberg MD: Albumin therapy improves local vascular dynamics in a rat model of primary microvascular thrombosis: a two-photon laserscanning microscopy study. Stroke 39:198-204, 2008

115. O'Bryant Z, Vann KT, Xiong ZG: Translational strategies for neuroprotection in ischemic stroke-focusing on acidsensing ion channel 1a. Transl Stroke Res 5:59-68, 2014

116. Okun E, Griffioen KJ, Lathia JD, Tang SC, Mattson MP, Arumugam TV: Toll-like receptors in neurodegeneration. Brain Res Brain Res Rev 59:278-292, 2009

117. Olney JW: Neurotoxicity of NMDA receptor antagonists: an overview. Psychopharmacol Bull 30:533-540, 1994

118. Onetti Y, Dantas AP, Pérez B, Cugota R, Chamorro A, Planas AM, et al: Middle cerebral artery remodeling following transient brain ischemia is linked to early postischemic hyperemia: a target of uric acid treatment. Am J Physiol Heart Circ Physiol 308:H862-H874, 2015

119. Park HP, Nimmagadda A, DeFazio RA, Busto R, Prado R, Ginsberg MD: Albumin therapy augments the effect of thrombolysis on local vascular dynamics in a rat model of arteriolar thrombosis: a two-photon laser-scanning microscopy study. Stroke 39: 1556-1562, 2008

120. RANTTAS Investigators: A Randomized Trial of Tirilazad 
Mesylate in Patients with Acute Stroke (RANTTAS). Stroke 27:1453-1458, 1996

121. Rikitake Y, Kim HH, Huang Z, Seto M, Yano K, Asano T, et al: Inhibition of Rho kinase (ROCK) leads to increased cerebral blood flow and stroke protection. Stroke 36:22512257,2005

122. Rodrigues FB, Neves JB, Caldeira D, Ferro JM, Ferreira JJ, Costa J: Endovascular treatment versus medical care alone for ischaemic stroke: systematic review and meta-analysis. BMJ 353:i1754, 2016

123. Romanos E, Planas AM, Amaro S, Chamorro A: Uric acid reduces brain damage and improves the benefits of rt-PA in a rat model of thromboembolic stroke. J Cereb Blood Flow Metab 27:14-20, 2007

124. Sacco RL, DeRosa JT, Haley EC Jr, Levin B, Ordronneau $\mathrm{P}$, Phillips SJ, et al: Glycine antagonist in neuroprotection for patients with acute stroke: GAIN Americas: a randomized controlled trial. JAMA 285:1719-1728, 2001

125. Saver JL, Starkman S, Eckstein M, Stratton SJ, Pratt FD, Hamilton S, et al: Prehospital use of magnesium sulfate as neuroprotection in acute stroke. N Engl J Med 372:528536,2015

126. Scandinavian Stroke Study Group: Multicenter trial of hemodilution in acute ischemic stroke. Results of subgroup analyses. Stroke 19:464-471, 1988

127. Schäbitz WR, Li F, Fisher M: The N-methyl-D-aspartate antagonist CNS 1102 protects cerebral gray and white matter from ischemic injury following temporary focal ischemia in rats. Stroke 31:1709-1714, 2000

128. Secades JJ, Alvarez-Sabín J, Castillo J, Díez-Tejedor E, Martínez-Vila E, Ríos J, et al: Citicoline for Acute Ischemic Stroke: a systematic review and formal meta-analysis of randomized, double-blind, and placebo-controlled trials. J Stroke Cerebrovasc Dis 25: 1984-1996, 2016

129. Sena E, Wheble P, Sandercock P, Macleod M: Systematic review and meta-analysis of the efficacy of tirilazad in experimental stroke. Stroke 38:388-394, 2007

130. Sheth KN, Elm JJ, Molyneaux BJ, Hinson H, Beslow LA, Sze GK, et al: Safety and efficacy of intravenous glyburide on brain swelling after large hemispheric infarction (GAMES-RP): a randomised, double-blind, placebo-controlled phase 2 trial. Lancet Neurol 15:1160-1169, 2016

131. Sheth KN, Kimberly WT, Elm JJ, Kent TA, Mandava $\mathrm{P}$, Yoo AJ, et al: Pilot study of intravenous glyburide in patients with a large ischemic stroke. Stroke 45:281-283, 2014

132. Shibuya M, Hirai S, Seto M, Satoh S, Ohtomo E: Effects of fasudil in acute ischemic stroke: results of a prospective placebo-controlled double-blind trial. J Neurol Sci 238:31-39, 2005

133. Shinohara Y, Saito I, Kobayashi S, Uchiyama S: Edaravone (radical scavenger) versus sodium ozagrel (antiplatelet agent) in acute noncardioembolic ischemic stroke (EDO trial). Cerebrovasc Dis 27:485-492, 2009

134. Shuaib A, Lees KR, Lyden P, Grotta J, Davalos A, Davis SM, et al: NXY-059 for the treatment of acute ischemic stroke. N Engl J Med 357:562-571, 2007

135. Siepmann T, Penzlin AI, Kepplinger J, Illigens BM, Weidner K, Reichmann H, et al: Selective serotonin reuptake inhibitors to improve outcome in acute ischemic stroke: possible mechanisms and clinical evidence. Brain Behav 5:e00373, 2015

136. Spiotta AM, Chaudry MI, Hui FK, Turner RD, Kellogg RT, Turk AS: Evolution of thrombectomy approaches and devices for acute stroke: a technical review. J Neurointerv Surg 7:2-7, 2015

137. Stokum JA, Gerzanich V, Simard JM: Molecular pathophysiology of cerebral edema. J Cereb Blood Flow Metab 36:513-538, 2016
138. Stoll G, Jander S, Schroeter M: Inflammation and glial responses in ischemic brain lesions. Prog Neurobiol 56:149-171, 1998

139. Stroke Therapy Academic Industry Roundtable (STAIR): Recommendations for standards regarding preclinical neuroprotective and restorative drug development. Stroke 30:2752-2758, 1999

140. Sydserff SG, Cross AJ, Green AR: The neuroprotective effect of chlormethiazole on ischaemic neuronal damage following permanent middle cerebral artery ischaemia in the rat. Neurodegeneration 4:323-328, 1995

141. Tahir RA, Pabaney AH: Therapeutic hypothermia and ischemic stroke: a literature review. Surg Neurol Int 7 (Suppl 14):S381-S386, 2016

142. Takahashi M, Kohara A, Shishikura J, Kawasaki-Yatsugi S, Ni JW, Yatsugi S, et al: YM872: a selective, potent and highly water-soluble $\alpha$-amino-3-hydroxy-5-methylisoxazole-4-propionic acid receptor antagonist. CNS Drug Rev 8:337-352, 2002

143. Teal P, Davis S, Hacke W, Kaste M, Lyden PD, Fierus M: A randomized, double-blind, placebo-controlled trial to evaluate the efficacy, safety, tolerability, and pharmacokinetic/pharmacodynamic effects of a targeted exposure of intravenous repinotan in patients with acute ischemic stroke: modified Randomized Exposure Controlled Trial (mRECT). Stroke 40:3518-3525, 2009

144. Tirilazad International Steering Committee: Tirilazad mesylate in acute ischemic stroke: a systematic review. Stroke 31:2257-2265, 2000

145. Tosun C, Kurland DB, Mehta R, Castellani RJ, deJong JL, Kwon MS, et al: Inhibition of the Sur1-Trpm4 channel reduces neuroinflammation and cognitive impairment in subarachnoid hemorrhage. Stroke 44:3522-3528, 2013

146. Trust Study Group: Randomised, double-blind, placebocontrolled trial of nimodipine in acute stroke. Lancet 336:1205-1209, 1990

147. Turski L, Huth A, Sheardown M, McDonald F, Neuhaus R, Schneider HH, et al: ZK200775: a phosphonate quinoxalinedione AMPA antagonist for neuroprotection in stroke and trauma. Proc Natl Acad Sci U S A 95:10960-10965, 1998

148. van der Worp HB, Macleod MR, Bath PM, Demotes J, Durand-Zaleski I, Gebhardt B, et al: EuroHYP-1: European multicenter, randomized, phase III clinical trial of therapeutic hypothermia plus best medical treatment vs. best medical treatment alone for acute ischemic stroke. Int J Stroke 9:642-645, 2014

149. Wahlgren NG, MacMahon DG, DeKeyser J, Indredavik B, Ryman T: Intravenous Nimodipine West European Stroke Trial (INWEST) of nimodipine in the treatment of acute ischaemic stroke. Cerebrovasc Dis 4:204-210, 1994

150. Wahlgren NG, Ranasinha KW, Rosolacci T, Franke CL, van Erven PM, Ashwood T, et al: Clomethiazole acute stroke study (CLASS): results of a randomized, controlled trial of clomethiazole versus placebo in 1360 acute stroke patients. Stroke 30:21-28, 1999

151. Walters MR, Kaste M, Lees KR, Diener HC, Hommel M, De Keyser J, et al: The AMPA antagonist ZK 200775 in patients with acute ischaemic stroke: a double-blind, multicentre, placebo-controlled safety and tolerability study. Cerebrovasc Dis 20:304-309, 2005

152. Wang Q, Tang XN, Yenari MA: The inflammatory response in stroke. J Neuroimmunol 184:53-68, 2007

153. Warach S, Pettigrew LC, Dashe JF, Pullicino P, Lefkowitz DM, Sabounjian L, et al: Effect of citicoline on ischemic lesions as measured by diffusion-weighted magnetic resonance imaging. Ann Neurol 48:713-722, 2000

154. Wei Y, Yemisci M, Kim HH, Yung LM, Shin HK, Hwang SK, et al: Fingolimod provides long-term protection in 
rodent models of cerebral ischemia. Ann Neurol 69:119129,2011

155. Westermaier T, Zausinger S, Baethmann A, SchmidElsaesser R: Dose finding study of intravenous magnesium sulphate in transient focal cerebral ischemia in rats. Acta Neurochir (Wien) 147:525-532, 2005

156. Willmot M, Gray L, Gibson C, Murphy S, Bath PM: A systematic review of nitric oxide donors and $\mathrm{L}$-arginine in experimental stroke; effects on infarct size and cerebral blood flow. Nitric Oxide 12:141-149, 2005

157. Yamaguchi T, Sano K, Takakura K, Saito I, Shinohara Y, Asano T, et al: Ebselen in acute ischemic stroke: a placebocontrolled, double-blind clinical trial. Stroke 29:12-17, 1998

158. Yang Y, Li Q, Ahmad F, Shuaib A: Survival and histological evaluation of therapeutic window of post-ischemia treatment with magnesium sulfate in embolic stroke model of rat. Neurosci Lett 285:119-122, 2000

159. Zhang E, Liao P: Brain transient receptor potential channels and stroke. J Neurosci Res 93:1165-1183, 2015

160. Zhang J, Yang J, Zhang C, Jiang X, Zhou H, Liu M: Calcium antagonists for acute ischemic stroke. Cochrane Database Syst Rev (5):CD001928, 2012
161. Zhang RL, Chopp M, Jiang N, Tang WX, Prostak J, Manning AM, et al: Anti-intercellular adhesion molecule-1 antibody reduces ischemic cell damage after transient but not permanent middle cerebral artery occlusion in the Wistar rat. Stroke 26: 1438-1443, 1995

\section{Disclosures}

The authors report no conflict of interest concerning the materials or methods used in this study or the findings specified in this paper.

\section{Author Contributions}

Conception and design: Park, Karsy. Acquisition of data: Karsy, Brock, Guan. Drafting the article: Karsy, Brock, Guan. Critically revising the article: Park, Taussky, Kalani. Reviewed submitted version of manuscript: Park, Karsy, Taussky, Kalani. Approved the final version of the manuscript on behalf of all authors: Park.

\section{Correspondence}

Min S. Park, Department of Neurosurgery, University of Utah, Clinical Neurosciences Center, 175 North Medical Dr. East, Salt Lake City, UT 84132. email: min.park@hsc.utah.edu. 